\title{
Vascular Cell Adhesion Molecule-1 (VCAM-1) Gene Transcription and Expression Are Regulated through an Antioxidant-sensitive Mechanism in Human Vascular Endothelial Cells
}

\author{
Nobuyuki Marui, * Margaret K. Offermann, "\$ Robert Swerlick," Charles Kunsch," Craig A. Rosen," \\ Mushtaq Ahmad, * R. Wayne Alexander, * and Russell M. Medford* \\ Divisions of *Cardiology and ${ }^{\ddagger}$ Hematology/Oncology, Department of Medicine, the ${ }^{\S}$ Winship Cancer Center, \\ and "Department of Dermatology, Emory University School of Medicine, Atlanta, Georgia 30322; \\ and 'Roche Institute of Molecular Biology, Nutley, New Jersey 07110
}

\begin{abstract}
Oxidative stress and expression of the vascular cell adhesion molecule-1 (VCAM-1) on vascular endothelial cells are early features in the pathogenesis of atherosclerosis and other inflammatory diseases. Regulation of VCAM-1 gene expression may be coupled to oxidative stress through specific reduction-oxidation (redox ) sensitive transcriptional or posttranscriptional regulatory factors. In cultured human umbilical vein endothelial (HUVE) cells, the cytokine interleukin $1 \beta$ (IL-1 $\beta$ ) activated VCAM-1 gene expression through a mechanism that was repressed $\sim 90 \%$ by the antioxidants pyrrolidine dithiocarbamate (PDTC) and $\mathrm{N}$-acetylcysteine (NAC). Furthermore, PDTC selectively inhibited the induction of VCAM-1, but not intercellular adhesion molecule-1 (ICAM-1), mRNA and protein accumulation by the cytokine tumor necrosis factor- $\alpha$ (TNF $\alpha$ ) as well as the noncytokines bacterial endotoxin lipopolysaccharide (LPS) and double-stranded RNA, poly(I:C) (PIC). PDTC also markedly attenuated TNF $\alpha$ induction of VCAM-1-mediated cellular adhesion. In a distinct pattern, PDTC partially inhibited E-selectin gene expression in response to TNF $\alpha$ but not to LPS, IL-1 $\beta$, or PIC. TNF $\alpha$ and LPS-mediated transcriptional activation of the human VCAM1 promoter through NF- $\kappa$ B-like DNA enhancer elements and associated NF- $\kappa$ B-like DNA binding proteins was inhibited by PDTC. These studies suggest a molecular linkage between an antioxidant sensitive transcriptional regulatory mechanism and VCAM-1 gene expression that expands on the notion of oxidative stress as an important regulatory signal in the pathogenesis of atherosclerosis. (J. Clin. Invest. 1993. 92:1866-1874.) Key words: antioxidant $\bullet$ cell adhesion molecules $\bullet$ endothelial cells • NF $k$ B • pyrrolidine dithiocarbamate
\end{abstract}

\section{Introduction}

In the inflammatory response, leukocyte recruitment to the endothelium is mediated by the interaction of adhesion molecule receptors expressed on the surface of endothelial cells with counterreceptors expressed on immune cells. Endothelial cells

Address reprint requests to Dr. Russell M. Medford, Cardiovascular Division, Department of Medicine, Emory University School of Medicine, 1639 Pierce Drive-P.O. Drawer LL, Atlanta, GA 30322.

Received for publication 9 February 1993 and in revised form 3 May 1993.

J. Clin. Invest.

(C) The American Society for Clinical Investigation, Inc.

$0021-9738 / 93 / 10 / 1866 / 09 \$ 2.00$

Volume 92, October 1993, 1866-1874 play a major role in defining the types of leukocytes recruited, such as monocytes, lymphocytes, or neutrophils, by selectively expressing specific adhesion molecules, such as vascular cell adhesion molecule-1 (VCAM-1 ), ${ }^{1}$ intercellular adhesion molecule-1 (ICAM-1), or E-selectin, in response to various inflammatory stimuli $(1,2)$. An important example of this process is the localized endothelial expression of VCAM-1 and selective recruitment of mononuclear leukocytes to the vascular lesions observed in early atherosclerosis (3). VCAM-1 is a member of the immunoglobulin gene superfamily that mediates leukocyte binding to the endothelial cell through its interaction with its integrin counterreceptor, very late activation antigen-4 (VLA4) (4). Because of the selective expression of VLA-4 on monocytes and lymphocytes, but not neutrophils, VCAM-1 plays an important role in mediating mononuclear leukocyte-selective adhesion (4-9).

The nature of the inflammatory signals and associated molecular mechanisms that activate VCAM-1 gene expression in endothelial cells in the early atherogenic lesion are unknown. Whether similar or distinct mechanisms regulate ICAM-1 gene expression in the atherosclerotic setting is also unknown $(3,10$, 11). Factors commonly found in inflammatory atherogenic lesions, such as the cytokines TNF $\alpha$ and IL-1 $\beta$, induce the concurrent expression of VCAM-1, ICAM-1, and E-selectin in cultured endothelial cells (see reference 2 for review). This same pattern of expression is observed in culture with other agents such as bacterial endotoxin LPS and the synthetic double-stranded RNA, polyinosinic:polycitidylic acid, poly(I:C) (PIC) (12-14). Clearly, these factors alone cannot selectively activate VCAM-1 gene expression and this raises the issue of whether these factors activate VCAM-1, ICAM-1, and E-selectin expression through a common, or gene-specific, molecular regulatory pathway. Evidence for a VCAM-1-specific regulatory mechanism is suggested by the observation that IL-4 enhances TNF $\alpha$ activation of endothelial VCAM-1 expression (15) but represses TNF $\alpha$ activation of ICAM-1 and E-selectin expression (16). This raises the possibility that in addition to IL-4, other types of regulatory signals may interact with elements of a VCAM-1-specific regulatory mechanism to either activate or repress VCAM-1 expression independent of ICAM1 or E-selectin.

Oxidative stress may play an important role in regulating VCAM-1 gene expression. In the early atherogenic lesion, oxi-

1. Abbreviations used in this paper: HUVE, human umbilical vein endothelial (cells); ICAM-1, intercellular adhesion molecule-1; NAC, $N$ acetylcysteine; PDTC, pyrrolidine dithiocarbamate; PIC, poly(I:C), polyinosinic:polycitidylic acid; redox, reduction-oxidation; VCAM-1, vascular cell adhesion molecule. 
dative stress is manifested by the elevated production of reactive oxygen species by endothelial and smooth muscle cells that result in the oxidative modification of low density lipoprotein $(17,18)$. This is likely due in part to both paracrine and autocrine mechanisms by which the cytokines IL- $1 \beta$ and TNF $\alpha$, derived from both inflammatory and endothelial cells, induce the cellular synthesis of reactive oxygen species $(19,20)$. It is in this oxidative milieu that endothelial VCAM-1 expression and consequent monocyte accumulation is observed in the early atherogenic lesion $(3,21)$. These observations suggest that the activation of VCAM-1 gene expression might be distinguished by its sensitivity to modulation by oxidation-mediated signals.

Recent studies of the human VCAM-1 promoter suggest that TNF $\alpha$ activation of VCAM-1 transcription in endothelial cells is dependent, at least in part, on the activation of NF- $\kappa$ Blike transcriptional regulatory proteins $(22,23)$. NF- $\kappa \mathrm{B}$ is a ubiquitously expressed multisubunit transcription factor whose activation in several cell types by a large and diverse group of agents such as TNF $\alpha$, IL- $1 \beta$, LPS, PIC, as well as the oxidant $\mathrm{H}_{2} \mathrm{O}_{2}$ can be specifically inhibited by antioxidants such as $\mathrm{N}$-acetylcysteine (NAC) and pyrrolidine dithiocarbamate (PDTC) (24-26). This has led to the hypothesis that oxygen radicals play an important role in the activation of NF- $\mathrm{B}$ through an as yet undefined reduction-oxidation (redox) mechanism (26). By extrapolation, oxidative stress in the atherosclerotic lesion may play a role in regulating VCAM-1 gene expression through an NF- $\kappa \mathrm{B}-$ like redox sensitive transcriptional regulatory protein.

We have tested the hypothesis that cytokines selectively induced VCAM-1 gene regulation through an antioxidant sensitive pathway in human umbilical vein endothelial (HUVE) cells. We have identified a regulatory pathway controlling VCAM-1 expression that is sensitive to antioxidants and distinct from ICAM-1 and E-selectin expression. In the process, we have shown a possible molecular linkage between redox sensitive regulatory mechanisms in the endothelial cell and VCAM-1 gene transcription and expression that expands on the notion of oxidative stress as an important regulatory signal in the expression of VCAM-1 in the pathogenesis of atherosclerosis.

\section{Methods}

Cell culture. HUVE cells were isolated from human umbilical veins that were cannulated, perfused with Hanks' solution to remove blood, and then incubated with $1 \%$ collagenase for $15 \mathrm{~min}$ at $37^{\circ} \mathrm{C}$. After removal of collagenase, cells were cultured in M199 medium supplemented with $20 \%$ FBS (HyClone Laboratories, Logan, UT), 16 U/ml heparin (ESI Pharmaceuticals, Cherry Hill, NJ), $50 \mu \mathrm{g} / \mathrm{ml}$ endothelial cell growth supplement (Collaborative Research Inc., Bedford, MA), $25 \mathrm{mM}$ Hepes buffer, $2 \mathrm{mM}$ L-glutamine, $100 \mathrm{U} / \mathrm{ml}$ penicillin, and $100 \mu \mathrm{g} / \mathrm{ml}$ streptomycin, and grown at $37^{\circ} \mathrm{C}$ on tissue culture plates coated with $0.1 \%$ gelatin. Cells were passaged at confluence by splitting 1:4 and were used within the first eight passages.

Incubation with cytokines and other reagents. Confluent HUVE cells received fresh media and then the indicated concentrations of PDTC were added as pretreatment for $30 \mathrm{~min}$ or $1 \mathrm{~h}$ before adding cytokines. Cytokines and other inducers were directly added to medium for the times and at the concentrations indicated in each experiment. Human recombinant IL- $1 \beta$ was the generous gift of The Upjohn Company (Kalamazoo, MI). Human recombinant TNF $\alpha$ was obtained from Boehringer-Mannheim Biochemicals (Indianapolis, IN). Bacterial LPS, PIC, NAC, and PDTC were obtained from Sigma Chemical Co. (St. Louis, MO). NAC was neutralized to $\mathrm{pH} 7.0$ before use. All other reagents were of reagent grade.
Northern blot analysis. Total cellular RNA was isolated by a single extraction using an acid guanidium thiocyanate-phenol-chloroform (27). Total cellular RNA ( $20 \mu \mathrm{g}$ ) was size-fractionated using $1 \%$ agarose formaldehyde gels in the presence of $1 \mu \mathrm{g} / \mathrm{ml}$ ethidium bromide. The RNA was transferred to a nitrocellulose filter and covalently linked by ultraviolet irradiation using a Stratlinker UV crosslinker (Stratagene Inc., La Jolla, CA). Hybridizations were performed at $42^{\circ} \mathrm{C}$ for $18 \mathrm{~h}$ in $5 \times \operatorname{SSC}(1 \times=150 \mathrm{mM} \mathrm{NaCl}, 15 \mathrm{mM} \mathrm{Na}$ citrate $), 1 \%$ sodium dodecyl sulfate, $5 \times$ Denhardt solution, $50 \%$ formamide, $10 \%$ dextran sulfate, and $100 \mu \mathrm{g} / \mathrm{ml}$ of sheared denatured salmon sperm DNA. Approximately $1-2 \times 10^{6} \mathrm{cpm} / \mathrm{ml}$ of labeled probe ( $\mathrm{sp}$ act $>10^{8} \mathrm{cpm} / \mu \mathrm{g}$ DNA) was used per hybridization. After hybridization, filters were washed with a final stringency of $0.2 \times \mathrm{SSC}$ at $55^{\circ} \mathrm{C}$. The nitrocellulose membrane was soaked for stripping the probe with boiled water before rehybridization. Autoradiography was performed with an intensifying screen at $-70^{\circ} \mathrm{C}$. Laser densitometry and digital analysis of scanned images were used for quantitation of autoradiograms.

${ }^{32} \mathrm{P}$-labeled DNA probes were prepared using the random primer oligonucleotide method (28). The VCAM-1 probe was a Hind III-Xho I fragment of the human cDNA consisting of nucleotides 132-1814 (29). The ICAM-1 probe was an Eco RI fragment of human cDNA (30). The E-selectin probe was a 1.35-kb Eco RI fragment of human cDNA (31).

Enzyme linked immunosorbent assay (ELISA). HUVE cells were plated on 96-well tissue culture plates 48-72 h before the assay. Primary antibodies in M199 medium with 5\% FBS were added to each well and incubated for $1 \mathrm{~h}$ at $37^{\circ} \mathrm{C}$. The cells were then washed and incubated for $1 \mathrm{~h}$ with peroxidase conjugated goat anti-mouse IgG (Bio-Rad Laboratories, Richmond, CA) diluted 1/500 in M199 medium with 5\% FBS. The wells were then washed and the binding of antibody was detected by the addition of $100 \mu \mathrm{l}$ of $0.1 \mathrm{mg} / \mathrm{ml} \mathrm{3,3,5,5^{ \prime } -}$ tetramethyl-benzidine (TMB) (Sigma Chemical Co.) with $0.003 \%$ $\mathrm{H}_{2} \mathrm{O}_{2}$. The reaction was stopped by the addition of $25 \mu \mathrm{l}$ of $8 \mathrm{~N}$ sulfuric acid. Plates were read on an ELISA reader (Bio-Rad Laboratories) at OD $450 \mathrm{~nm}$ after blanking on rows stained only with second step antibody. Data represents the means of quadruplicate samples. mAb 4B9 recognizing VCAM-1 and $\mathrm{mAb}$ E9A1F1 recognizing E-selectin were the generous gifts of Dr. John Harlan (University of Washington) and Dr. Barry Wolitsky (Hoffmann La Roche, Nutley, NJ), respectively. mAb 84H 10 recognizing ICAM-1 was obtained from a hybridoma cell line.

Cell adherence assay. HUVE cells were plated into gelatin coated 48-well tissue culture plates at a concentration of $5 \times 10^{4}$ cells per well and allowed to grow to confluence. Cells were then stimulated with PDTC $(50 \mu \mathrm{M} \times 7 \mathrm{~h}), \mathrm{TNF} \alpha(100$ or $500 \mathrm{U} / \mathrm{ml} \times 6 \mathrm{~h})$, or coincubated with both PDTC and TNF $\alpha$ after PDTC preincubation (1 h). Molt-4 cells (American Type Culture Collection, Rockville, MD) were grown in RPMI 1640 with $10 \%$ FBS, $2 \mathrm{mM}$ glutamine, $100 \mathrm{U} / \mathrm{ml}$ of penicillin, $100 \mu \mathrm{g} / \mathrm{ml}$ streptomycin, and $250 \mu \mathrm{g} / \mathrm{ml}$ of amphotericin B. Molt4 cells $\left(5 \times 10^{6}\right.$ cells in $\left.5 \mathrm{ml}\right)$ were labeled with ${ }^{51} \mathrm{Cr}$ by overnight incubation with $200 \mu \mathrm{Ci}$ of ${ }^{51} \mathrm{Cr}$. Cells were then washed and resuspended at a concentration of $1.5 \times 10^{5}$ cells $/ 50 \mu l$. HUVE cells were washed with Hepes-buffered saline solution (with calcium and magnesium) and 5\% FBS, and then preincubated for $15 \mathrm{~min}$ at room temperature with Hepes-buffered saline solution and 5\% FBS alone, or with tissue culture supernatants containing mAb recognizing VCAM-1 (mAb P3C4, generous gift of Dr. Elizabeth Wayner). $50 \mu \mathrm{l}$ of media containing $1.5 \times 10^{5}$ Molt-4 cells was added to each well and incubated for $60 \mathrm{~min}$ at $37^{\circ} \mathrm{C}$ with $5 \% \mathrm{CO}_{2}$. HUVE cells monolayers were then washed twice and $50 \mu \mathrm{l}$ of $1 \%$ SDS was added to each well. Adherent counts were harvested with a cotton swab and counted in a gamma counter (model 5500, Beckman Instruments, Inc., Palo Alto, CA). The percent binding was calculated as follows; $\%$ binding $=[($ adherent counts - background counts)/(total counts - background counts)] $\times$ 100. All data points were done at least in triplicate.

Transient DNA transfection. $24 \mathrm{~h}$ before transfection HUVE cells were split at the ratio that would give $60-70 \%$ confluence in $100-\mathrm{mm}$ tissue culture plates. After the medium was switched to Dulbecco's 
modified Eagle's medium containing $10 \%$ FBS, the cells were transfected with $30 \mu \mathrm{g}$ of reporter plasmid by the calcium phosphate coprecipitation technique using standard techniques (32). $4 \mathrm{~h}$ after transfection, cells were rinsed with phosphate-buffered saline and replaced with endothelial cell growth media. After a 24-hour recovery period, cells were either pretreated or not with $100 \mu \mathrm{M}$ PDTC and after $1 \mathrm{~h}$ exposed to cytokines that were added directly to the plates. $18 \mathrm{~h}$ later, cell extracts were prepared by rapid freeze-thaw in $0.25 \mathrm{M}$ Tris, pH 8.0. Protein content was determined using the Bradford technique (33). $40 \mu \mathrm{g}$ of protein of each cell extract was assayed for chloramphenicol acetyl transferase (CAT) activity and reaction were done in $4 \mathrm{~h}$ according to standard protocols (32). Each assay was performed in duplicate from at least two separate experiments. The reporter plasmid p288VCAMCAT (22) was a generous gift of Dr. Douglas Dean (Washington University).

Nuclear extract preparation and gel shift analysis. Confluent HUVE cells were pretreated for $1 \mathrm{~h}$ or untreated with $100 \mu \mathrm{M}$ PDTC, then exposed to either TNF $\alpha(100 \mathrm{U} / \mathrm{ml})$ or LPS $(100 \mathrm{ng} / \mathrm{ml})$ for $1 \mathrm{~h}$. Nuclear proteins were purified by a modification of (34). Briefly, after washing with phosphate-buffered saline, cells were centrifuged and the cell pellet suspended in $500 \mu \mathrm{l}$ buffer A ( $10 \mathrm{mM}$ Hepes, pH 7.9, $1.5 \mathrm{mM}$ $\mathrm{MgCl}_{2}, 10 \mathrm{mM} \mathrm{KCl}$, and $1.0 \mathrm{mM}$ DTT). After recentrifugation, the cells were resuspended in $80 \mu$ l buffer A containing $0.1 \%$ Triton-X-100 by gentle pipetting. After incubating for $10 \mathrm{~min}$ at $4^{\circ} \mathrm{C}$, the homogenate was centrifuged and the nuclear pellet was washed once with buffer $A$ and resuspended in $70 \mu$ lof buffer $\mathrm{C}$ ( $20 \mathrm{mM}$ Hepes, pH 7.9, $25 \%$ [ vol/vol] glycerol, $0.42 \mathrm{M} \mathrm{NaCl}, 1.5 \mathrm{mM} \mathrm{MgCl}_{2}, 0.2 \mathrm{mM}$ EDTA, $1 \mathrm{mM}$ DTT). This suspension was incubated for $30 \mathrm{~min}$ at $4^{\circ} \mathrm{C}$ followed by centrifugation at $20,000 \mathrm{~g}$ for $10 \mathrm{~min}$. The resulting superna-

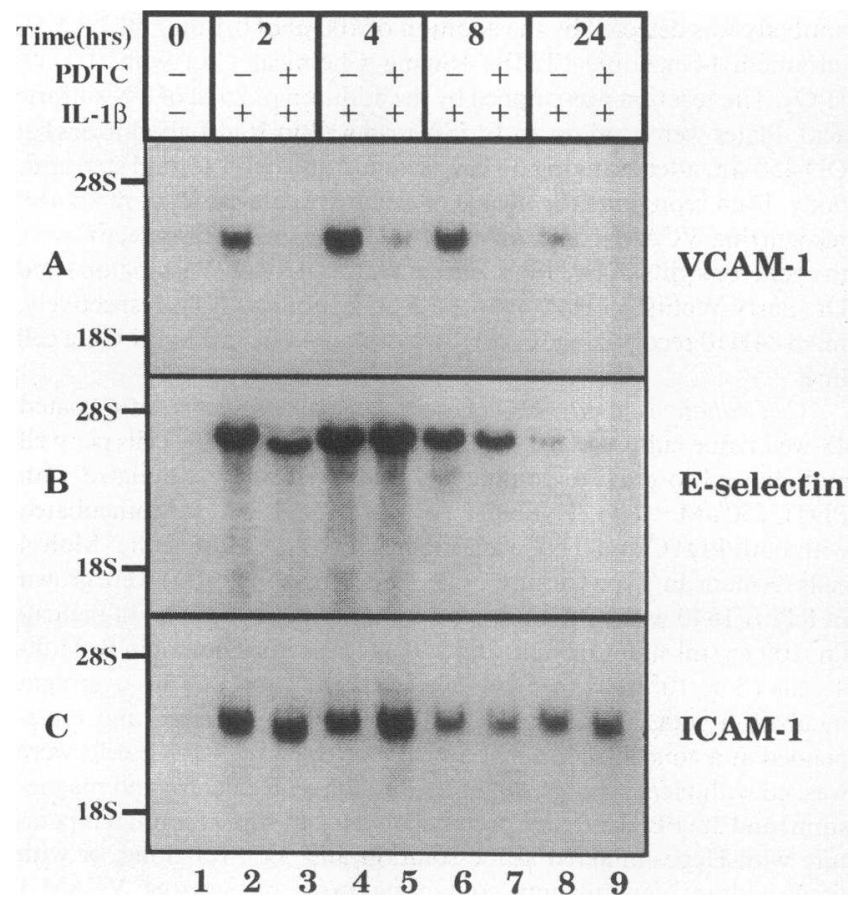

Figure 1. Induction of HUVE VCAM-1 mRNA by IL- $1 \beta$ is selectively inhibited by the antioxidant PDTC. After pretreatment for $30 \mathrm{~min}$ with $50 \mu \mathrm{M}$ PDTC, HUVE cells were exposed to IL-1 $\beta(10 \mathrm{U} / \mathrm{ml})$ in the continuous presence of $50 \mu \mathrm{M}$ PDTC. Total RNA was isolated and $20 \mu \mathrm{g}$ size-fractionated by denaturing $1.0 \%$ agarose-formaldehyde gel electrophoresis, transferred to nitrocellulose, and hybridized to either ${ }^{32} \mathrm{P}$-labeled human VCAM-1-specific $(A)$, E-selectin-specific $(B)$, or ICAM-1-specific $(C)$ cDNA, and visualized by autoradiography. Lane $1,0 \mathrm{~h}$; lanes $2,4,6,8, \mathrm{IL}-1 \beta$ alone for $2,4,8$, and $24 \mathrm{~h}$, respectively; lanes $3,5,7,9$, IL- $1 \beta$ with PDTC for $2,4,8$, and $24 \mathrm{~h}$, respectively. After washes, filters were exposed to X-ray film at $-70^{\circ} \mathrm{C}$ with one intensifying screen for $18 \mathrm{~h}$. tant was stored at $-70^{\circ} \mathrm{C}$ as nuclear extract. Protein concentrations were determined by the Bradford method (33). To minimize proteolysis, all buffers included 1.0 mM PMSF. The oligonucleotide wtVCAM was synthesized to encompass the two NF- $\mathrm{B}$ like sites (underlined) found at coordinates -77 and -63 of the human VCAM-1 promoter (22): 5'-CTGCCCTGGGTTTCCCCT TGAAGGGATTTCCCTCCGCC-

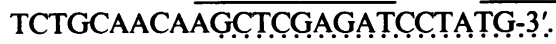

The dotted underlined sequence represents an unrelated tail sequence added to serve as template for synthesis of the double stranded form. The oligonucleotide mutVCAM was identical to wtVCAM except for four nucleotide mutations (boldface) in each of the two NFкB-like DNA binding sites: 5'-CTGCCCTGAGTCACGCCTTGAAGA GACATCAC T C CGCCT C TGCAACAAGC̣TṬG̣ẠG̣TTCC̣TAṬ̣: 3 '. A double-stranded oligonucleotide containing the NF- $\kappa$ B site (underlined) for the mouse immunoglobulin $\kappa$ gene, $\operatorname{Ig} \kappa \mathrm{B}$, was prepared by annealing complementary synthetic oligonucleotides creating the following sequence: 5'-AGCTTCAGAGGGGACTTTCCGAGAGG-3'. All oligonucleotides were prepared by the Emory University Microchemical Facility using standard solid-state chemistries. Radio labeled double-stranded DNA was made by annealing an oligonucleotide complementary to the $3^{\prime}$ end of the sequences listed above (dotted underlined) (5'-CATAGGATCTCGAGC-3') and extending with DNA polymerase and $50 \mu \mathrm{Ci}$ of $\left[{ }^{32} \mathrm{P}\right] \mathrm{dCTP}$ and unlabeled dATP, dGTP, and dTTP followed by the addition of $500 \mu \mathrm{M}$ unlabeled dCTP. Unincorporated nucleotides were removed by column chromatography over a Sephadex G-50 column. Cold double-stranded DNA was made identically except that unlabeled dCTP was substituted for labeled dCTP. The DNA binding reaction was performed at $30^{\circ} \mathrm{C}$ for $15 \mathrm{~min}$ in a volume of $20 \mu \mathrm{l}$, which contained $2-5 \mu \mathrm{g}$ of nuclear extract, $225 \mu \mathrm{g} / \mathrm{ml}$ bovine serum albumin, $1.0 \times 10^{5} \mathrm{cpm}^{32} \mathrm{P}$-labeled probe $(\sim 1 \mathrm{ng}), 0.1$ $\mathrm{mg} / \mathrm{ml}$ poly (dI-dC), $15 \mu$ l of binding buffer ( $12 \mathrm{mM}$ Hepes, $\mathrm{pH} 7.9,4$ $\mathrm{mM}$ Tris, $60 \mathrm{mM} \mathrm{KCl}, 1 \mathrm{mM}$ EDTA, $12 \%$ glycerol, $1 \mathrm{mM}$ DTT, and 1 mM PMSF) with or without 20-100-fold molar excess of cold competitor. Samples were subjected to electrophoresis on native $4 \% 1 \times$ Trisglycine-polyacrylamide gels.

\section{Results}

The antioxidant PDTC inhibits cytokine and noncytokine induction of VCAM-1, but not ICAM-1 or E-selectin, $M R N A$ accumulation in HUVE cells. To explore whether the IL- $1 \beta$ activated VCAM-1 gene expression through an oxidation-dependent mechanism, HUVE cells were exposed to the inducing cytokine, IL-1 $\beta(10 \mathrm{U} / \mathrm{ml})$ in the presence or absence of the antioxidant PDTC ( $50 \mu \mathrm{M})$ for up to $24 \mathrm{~h}$. PDTC is a dithiocarbamate that can function as an antioxidant through direct delivery of thiol groups to the cell (26). As shown in Fig. 1, IL- $1 \beta$ alone (lanes $2,4,6$, and 8 ) induced the expected rapid and transient induction of VCAM-1 (panel $A$ ), E-selectin (panel $B$ ), and ICAM-1 (panel $C$ ) mRNA accumulation, all of which peaked at $4 \mathrm{~h}$. In the presence of PDTC, IL- $1 \beta$ induction of VCAM-1 mRNA accumulation at all time points was inhibited by over $90 \%$ ( panel $A$ ). In contrast, ICAM-1 mRNA accumulation was unaffected except for a transient increase observed at $4 \mathrm{~h}$ (panel $C$, lane 5 ). Induction of E-selectin mRNA levels also exhibited a transient response to PDTC with a slight inhibition at 2 and $24 \mathrm{~h}$ (compare lanes 2 and 3, 8 and 9, panel $B$ ). Peak E-selectin mRNA levels induced at $4 \mathrm{~h}$ were unaffected (panel $B$, lanes 4 and 5). PDTC alone did not induce either VCAM-1 or E-selectin expression and dose-response analysis of the PDTC effect at $4 \mathrm{~h}$ after IL- $1 \beta$ activation established an $\mathrm{EC}_{50}$ of 5-50 $\mu \mathrm{M}$ for VCAM-1 expression (data not shown ). These data demonstrate that the activation of VCAM1 gene expression by IL- $1 \beta$ occurs through an thiol antioxidant-sensitive regulatory step. Furthermore, as E-selectin and 
ICAM-1 gene activation was unaffected, PDTC did not apparently block the functional activation of the IL- $1 \beta$ receptor by IL-1 $\beta$.

To explore whether PDTC-sensitive activation of VCAM-1 gene expression was specific for IL- $1 \beta$, other structurally and functionally distinct inducers of VCAM-1 gene expression were tested. PDTC selectively inhibited TNF $\alpha$, LPS, and PICmediated induction of VCAM-1 mRNA accumulation in HUVE cells after $4 \mathrm{~h}$ (Fig. $2 \mathrm{~A}$ ). Interestingly, PDTC partially inhibited E-selectin activation by TNF $\alpha$ but not by LPS or PIC (Fig. $2 \mathrm{~B}$ ). PDTC slightly augmented ICAM-1 induction in response to LPS but had no effect on TNF $\alpha$ or PIC mediated activation (Fig. $2 C$ ). These results suggest that PDTC-sensitive activation is a fundamental feature of VCAM-1 gene expression regardless of the inducing agent. In contrast, whether activation of the E-selectin genes is PDTC-sensitive or PDTCinsensitive signals appears to be dependent on the specific inducer. ICAM-1 gene expression was not affected by any activators so far tested.

An additional antioxidant was tested to characterize further the type of oxidation sensitive signal inhibited by PDTC in the cytokine-activated signal transduction pathway. As shown in

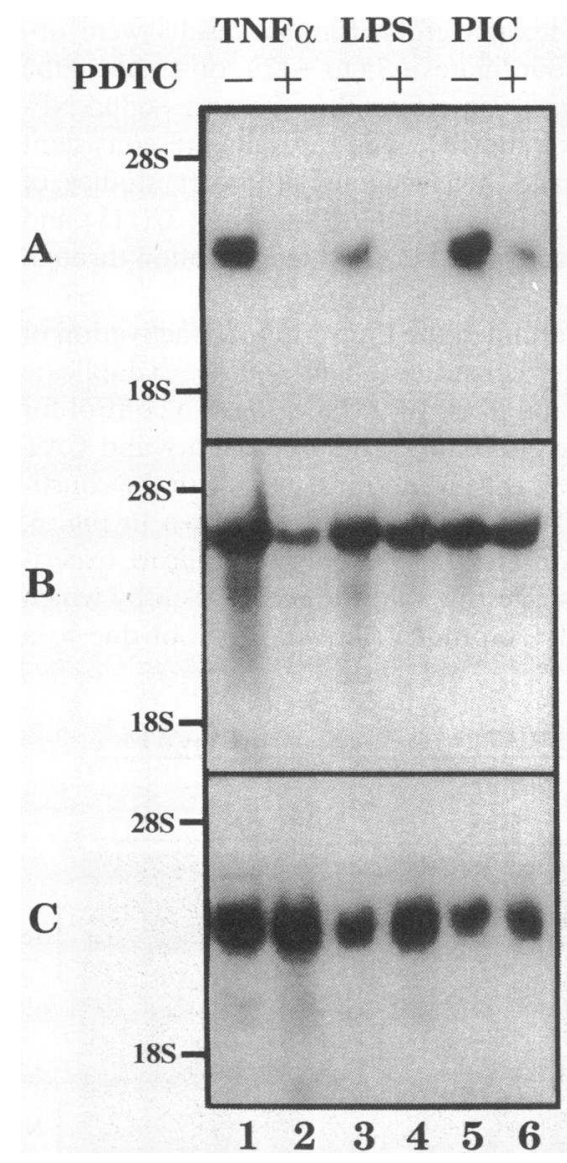

VCAM-1

E-selectin

Figure 2. PDTC selectively inhibits the induction of VCAM-1 mRNA accumulation by multiple types of inducing stimuli. As described in Fig. 1, HUVE cells were pretreated with $50 \mu \mathrm{M}$ PDTC, exposed for 4 $\mathrm{h}$ to the indicated agents, and assayed for VCAM-1 $(A)$, E-selectin $(B)$ and ICAM-1 $(C)$ mRNA accumulation. Lane 1, TNF $\alpha$ (100 U/ $\mathrm{ml}$ ); lane 2, TNF $\alpha$ + PDTC; lane 3, LPS (100 ng/ml); lane 4, LPS + PDTC; lane 5, PIC ( $100 \mu \mathrm{g} / \mathrm{ml})$, lane 6, PIC + PDTC. After washes, filters were exposed to $\mathrm{X}$-ray film at $-70^{\circ} \mathrm{C}$ with one intensifying screen for $18 \mathrm{~h}$.

Fig. 3, the structurally unrelated NAC effectively inhibited IL$1 \beta$ activation of VCAM- 1 mRNA accumulation although at considerably higher concentrations than PDTC. This concentration was established by dose-response studies (data not shown ) and correlated well with the ability of NAC to inhibit the expression of other redox-sensitive genes and transcriptional regulatory proteins (24). These results suggest that structurally distinct antioxidants may inhibit a common, oxidationsensitive regulatory step that activates VCAM-1 gene expression.

PDTC blocks the induction of functional VCAM-1 protein expression. To establish formally that PDTC blocked activation of functional VCAM-1, both VCAM-1 protein accumulation and VCAM-1-mediated cell adhesion were measured. VCAM-1 (4B9 [6]) and ICAM-1 (84H10 [35]) specific mAbs were used in an ELISA assay to quantitate the induction of cell surface VCAM-1 and ICAM-1 in cultured HUVE cells. As shown in Fig. 4, VCAM-1 expression was not detectable in unstimulated cells but was markedly induced $6 \mathrm{~h}$ after activation by IL- $1 \beta$, TNF $\alpha$, LPS, or PIC (open bars). Similar results were observed $24 \mathrm{~h}$ after induction (data not shown). In the presence of PDTC (closed bars), the induction of cell surface expression of VCAM- 1 by all agents tested was inhibited by $\sim 80-90 \%$. In contrast, the induced expression of cell surface ICAM-1 expression was unaffected under identical conditions. These results demonstrate that the ability of PDTC to inhibit the activation of VCAM-1 gene expression by diverse inducers occurs both at the mRNA and protein levels and argues against a translational and/or posttranslational mechanisms as the major target of PDTC action.

TNF $\alpha$ stimulated HUVE cells were utilized to explore whether a PDTC-sensitive mechanism might inhibit the induction of VCAM-1-mediated adhesion of HUVE cells to Molt-4

A

\section{ICAM-1}

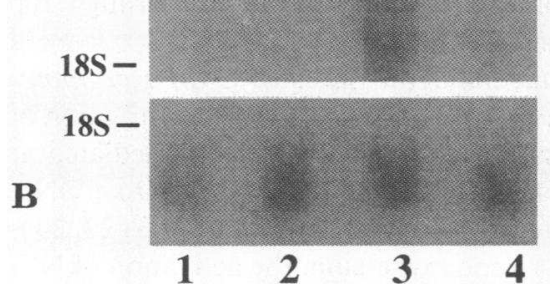

GAPDH

Figure 3. A structurally unrelated antioxidant, NAC, inhibits the induction of VCAM-1 mRNA by IL- $1 \beta$. As described in Fig. 2, HUVE cells were exposed to IL-1 $\beta$ either pretreated (lane 4) or not (lane 3) for 30 min with $30 \mathrm{mM}$ NAC. Total RNA was isolated, size fractionated, transferred and hybridized to either a VCAM-1-specific $(A)$ or constitutively expressed gene probe, glyceraldehyde phosphate dehydrogenase (GAPDH) $(B)$. After washes, filters were exposed to X-ray film at $-70^{\circ} \mathrm{C}$ with one intensifying screen for $18 \mathrm{~h}$. 

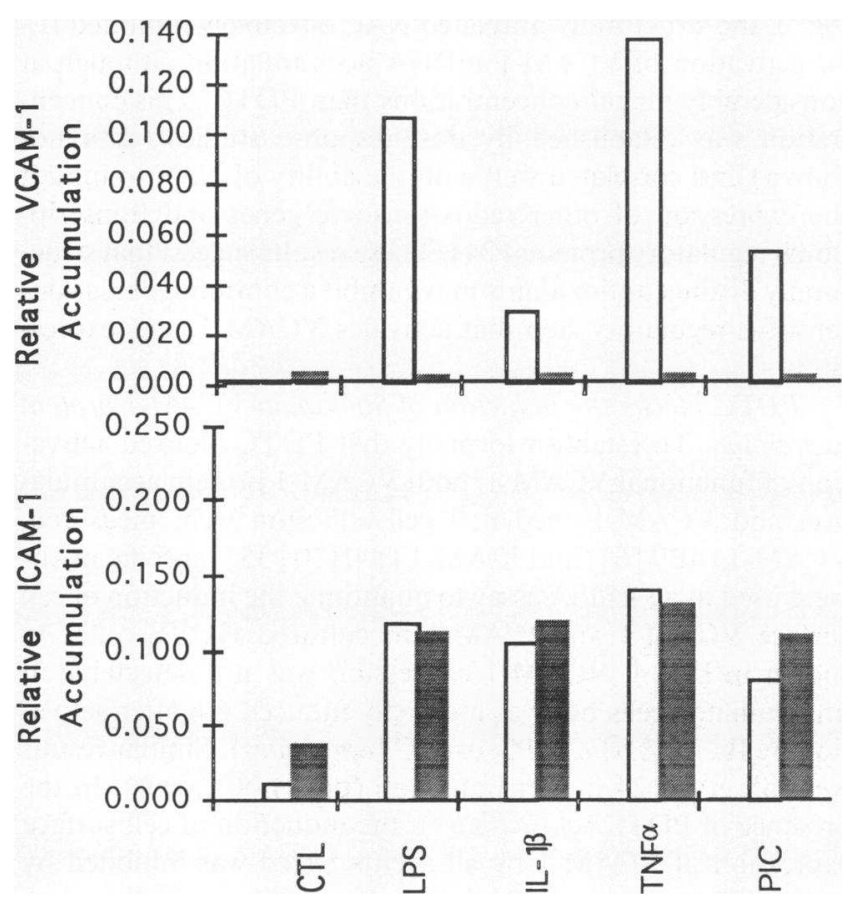

Figure 4. PDTC selectively inhibits the induction of cell surface expression of VCAM-1 by multiple types of inducing stimuli. Confluent HUVE cells were pretreated or not pretreated for 30 min with $50 \mu \mathrm{M}$ PDTC, then, except for CTL, exposed for $6 \mathrm{~h}$ to the indicated agents (LPS $100 \mathrm{ng} / \mathrm{ml}, \mathrm{IL}-1 \beta 10 \mathrm{U} / \mathrm{ml}, \mathrm{TNF} \alpha 100 \mathrm{U} / \mathrm{ml}$, PIC $100 \mu \mathrm{g} / \mathrm{ml}$ ) in the presence (solid bar) or absence (open bar) of PDTC. Cell surface expression was determined by primary binding with VCAM-1-specific (4B9) and ICAM-1-specific (84H10) mouse mAbs followed by secondary binding with a horseradish peroxidase-tagged goat anti-mouse (IgG). Quantitation was performed by determination of colorimetric conversion at $450 \mathrm{~nm}$ of TMB (see Methods).

cells. Molt- 4 cells express VLA- 4 and thus bind to TNF $\alpha$ activated HUVE cells via a VCAM-1-dependent mechanism (36). As shown in Fig. $5 A$, TNF $\alpha$ induced a statistically significant 2.5-fold increase in Molt-4 adhesion. Pretreatment of HUVE cells with PDTC markedly inhibited this adhesion to levels not significantly different than unstimulated HUVE cells ( $12 \%$ and $10 \%$ ). As shown in $B$, TNF $\alpha$-activated HUVE cells could be equally inhibited in their ability to adhere to Molt-4 cells either by pretreatment with PDTC or by blockade with a specific, anti-VCAM-1 antibody, $\mathrm{mABp} 3 \mathrm{c} 4$. These results suggest that PDTC inhibits the TNF $\alpha$-induced expression of functional VCAM-1 involved in cell-cell-adhesion through the VLA-4 integrin counterreceptor.

PDTC inhibits induction of the human VCAM-1 promoter transcriptional activity by TNF $\alpha$ and LPS. TNF $\alpha$ activation of VCAM-1 gene expression in endothelial cells is mediated at least in part transcriptionally through two NF- $\kappa$ B-like DNA binding elements located at coordinates -77 and $-63(22,23)$. Analogous to VCAM-1 gene expression, the activation of NF$\kappa$ B by IL- $1 \beta$, TNF $\alpha$, LPS, and PIC is inhibited by the antioxidants PDTC and NAC at least in the nonendothelial cells examined $(24,25)$. To determine whether VCAM-1 gene transcription was regulated by a similar redox-sensitive NF- $\kappa$ B like factor(s), the chimeric reporter gene p288VCAM-CAT, containing coordinates -288 to +22 of the human VCAM-1 promoter (22), was transiently transfected into HUVE cells and transcriptional activity was assayed by the accumulation of

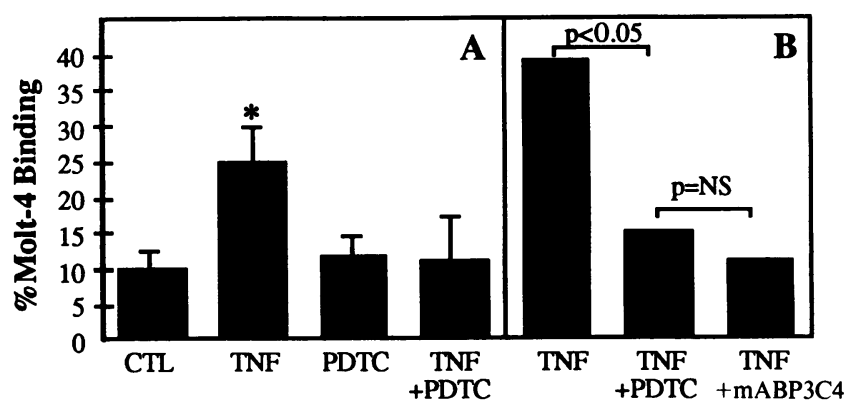

Figure 5. VCAM-1-mediated adhesion of Molt- 4 cells to TNF $\alpha$-activated HUVE cells is inhibited by PDTC. $(A)$ HUVE cells in 48-well dishes were either pretreated or not for $1 \mathrm{~h}$ with PDTC $(50 \mu \mathrm{M})$ followed by TNF $\alpha(100 \mathrm{U} / \mathrm{ml})$ or control. After $6 \mathrm{~h},{ }^{51} \mathrm{Cr}$-labeled Molt-4 cells were added and assayed for binding as described in Methods. ${ }^{*} P<0.05$ by Student's $t$ test. ( $B$ ) Same as in $A$ except TNF $\alpha$ was used at $500 \mathrm{U} / \mathrm{ml}$. Anti-VCAM-1 mAbP3C4 was added for $15 \mathrm{~min}$ before addition of Molt-4 cells. Percent binding was corrected for a $10 \%$ background binding in uninduced HUVE cells. NS = no significance. In all cases, $n>5$ separate assays.

CAT. As shown in Fig. 6, the addition of TNF $\alpha$ (duplicate experiments, lanes 5 and 6 ) or LPS (lane 9) induced VCAM-1 promoter activity at least fivefold. Similar results were obtained with smaller (coordinates -85 to +12 ) constructs of the VCAM-1 promoter each containing the -77 and $-63 b p$ NF$\kappa \mathrm{B}-$ like sites (data not shown). These results are consistent with prior deletion and heterologous promoter studies of TNF $\alpha$ activation of the human VCAM-1 gene $(22,23)$ and also suggest that LPS activates VCAM-1 transcription through a similar mechanism.

PDTC markedly inhibited the transcriptional activation of the VCAM-1 promoter construct either by TNF $\alpha$ (duplicate experiments, lanes 7 and 8) or LPS (lane 10). To control for potentially pleiotropic effects on promoter activity and CAT gene expression, HUVE cells were transfected with the constitutively active $\mathrm{pSV}_{2} \mathrm{CAT}$ reporter gene. As shown in Fig. 6, PDTC had no effect on $\mathrm{pSV}_{2} \mathrm{CAT}$ activity (duplicate experiments, lanes 11-14) suggesting that the mechanism by which PDTC blocks VCAM-1 promoter activation is not due to a

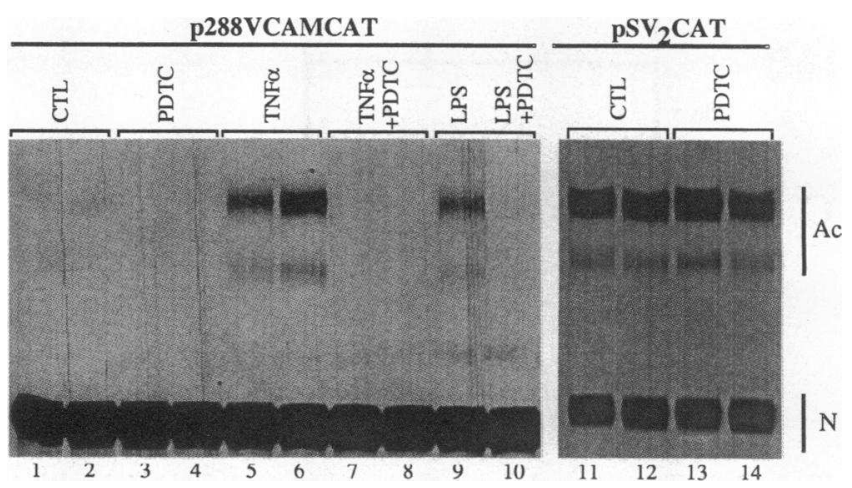

Figure 6. PDTC inhibits transcriptional activation of the human VCAM-1 promoter by TNF $\alpha$ and LPS. HUVE cells were transfected with either $30 \mu \mathrm{g}$ of $\mathrm{p} 288 \mathrm{VCAMCAT}$ or $\mathrm{pSV}_{2} \mathrm{CAT}$ as described in Methods. After an 18-h exposure to either TNF $\alpha(100 \mathrm{U} / \mathrm{ml})$ or LPS $(100 \mathrm{ng} / \mathrm{ml})$ in the prescence or absence of pretreatment with and continuing exposure to PDTC ( $100 \mu \mathrm{M})$, cytoplasmic extracts were prepared and CAT activity determined (Ac, acetylated; N, nonacetylated chloramphenicol). 
general or nonspecific inhibition of transcriptional regulatory factors. These results suggest that PDTC blocks VCAM-1 transcription and expression by interfering with the activation of a redox-sensitive transcriptional regulatory factor activated by either TNF $\alpha$ or LPS. Furthermore, as TNF $\alpha$ activates VCAM1 transcription through a defined, NF- $\kappa \mathrm{B}-$ like element pair in the VCAM-1 promoter (22, 23), PDTC may function through the DNA binding proteins that recognize these elements.

PDTC inhibits TNF $\alpha$ and LPS activation of DNA binding protein activity to the VCAM-1 NF- $\mathrm{B}$ like binding sites. To explore whether PDTC regulated VCAM-1 promoter activity through an NF- $\kappa \mathrm{B}$-like transcriptional regulatory factor, nuclear extracts from treated and untreated HUVE cells were assayed for DNA binding activity to a double-stranded oligonucleotide containing the VCAM- 1 NF- $\kappa$ B-like promoter elements located at positions -77 and -63 (wtVCAM, see Methods) $(22,23)$. As shown in Fig. $7 A$, two bands A and C, representing NF- $\kappa \mathrm{B}-$ like binding activity were induced in response

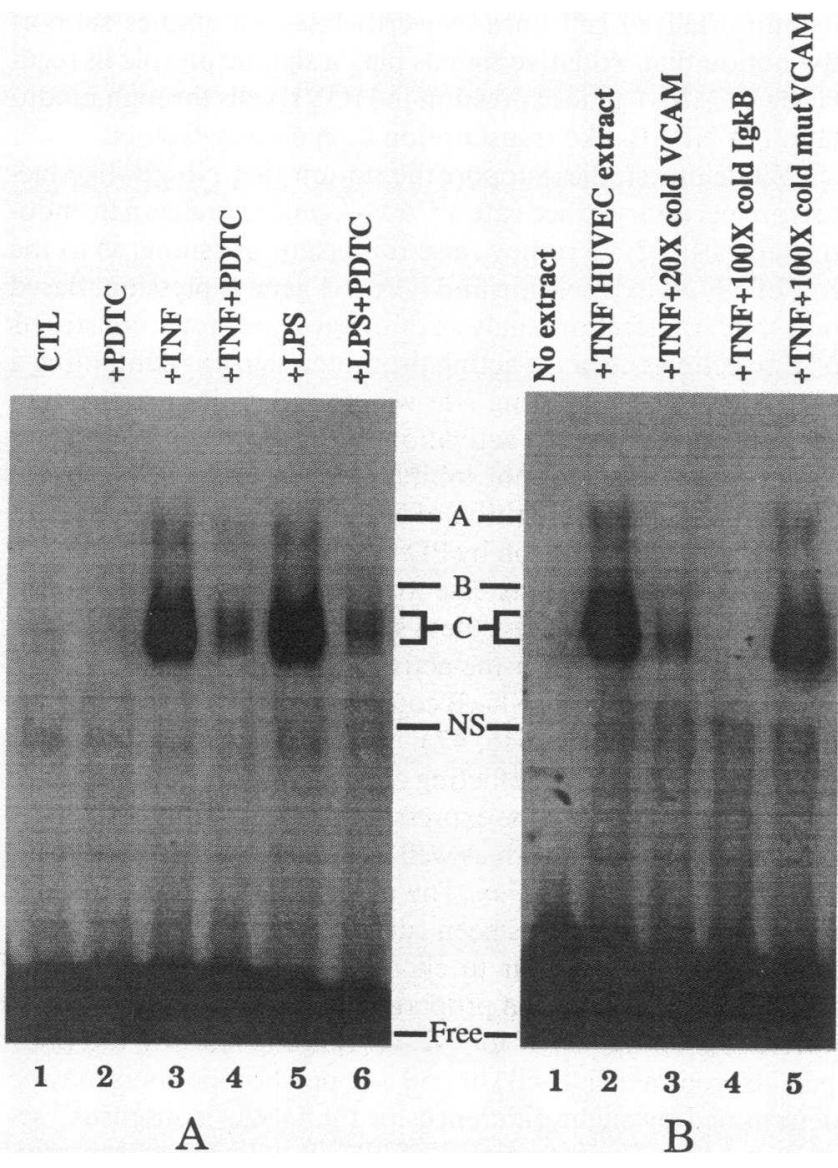

Figure 7. TNF $\alpha$ and LPS activate NF- $\kappa \mathrm{B}-$ like DNA binding activities that are blocked by PDTC. $(A)$ Confluent HUVE cells were either pretreated (lanes 4 and 6 ) or not pretreated with PDTC $(100 \mu \mathrm{M})$ (lanes 3 and 5$)$ for $1 \mathrm{~h}$, then exposed for $1 \mathrm{~h}$ to TNF $\alpha(100 \mathrm{U} / \mathrm{ml})$ and LPS $(100 \mathrm{ng} / \mathrm{ml})$, respectively. $5 \mu \mathrm{g}$ of nuclear extract was incubated with a double-stranded ${ }^{32} \mathrm{P}$-labeled wtVCAM, size fractionated on $4 \%$ native acrylamide gels, and exposed to autoradiography film. (B) Nuclear extracts from HUVE cells treated with TNF $\alpha$ (from $A$, lane 3 ) were incubated with radiolabeled wtVCAM oligonucleotide in the absence (lane 2) or presence of excess cold wtVCAM (lane 3), mouse $\operatorname{Ig} \kappa \mathrm{B}$ consensus sequence DNA (lane 4) or a wtVCAM mutated in its NF- $\kappa$ B sites (mutVCAM) (lane 5). Analysis was performed as in $A$. to a 1-h exposure to TNF $\alpha$ and LPS (lanes 3 and 5). With a short exposure, $\mathrm{C}$ band appeared to consist of at least three DNA binding proteins (data not shown). A weak band B was observed in uninduced cells (lane 1). Pretreatment of cells for $1 \mathrm{~h}$ with PDTC inhibited over $80 \%$ of the A and C complex DNA binding activity after TNF $\alpha$ and LPS activation (lanes 4 and 6). The specificity of these protein-DNA complexes for the NF- $\kappa$ B sequence was determined by competition binding experiments. As shown in $B$, competition with excess, wtVCAM (lane 3 ) and cold mouse immunoglobulin $\kappa \mathrm{B}$ sequences (lane 4 ) resulted in over $90 \%$ inhibition of binding. In contrast, cold excess oligonucleotide with four bases mutations within both NF- $\kappa$ B like sites ( mutVCAM) did not affect binding activity (lane 5 ). These studies demonstrate that the $A$ and $\mathrm{C}$ protein complexes, which bind specifically to the NF- $\kappa \mathrm{B}-$ like sequences found in wtVCAM, are activated by TNF $\alpha$ and LPS, and that their activation is inhibited by the antioxidant PDTC. This correlates well with PDTC's effect on VCAM-1 promoter activity and suggests that PDTC blocks the activation of VCAM-1 gene expression in HUVE cells by inhibiting the activation of these NF- $\kappa$ B-like DNA binding proteins.

\section{Discussion}

In response to a wide variety of cytokine and noncytokine inducers, vascular endothelial cells activate concurrently the expression of the adhesion molecule genes VCAM-1, ICAM-1, and E-selectin. However, the molecular mechanisms underlying this activation are not fully understood nor is it known whether, and to what degree, these genes are activated by common, or gene-specific, regulatory factors. We have established that the activation of endothelial cell VCAM-1 gene expression by cytokine and noncytokine inducers is regulated by a signal transduction mechanism sensitive to inhibition by antioxidants. Furthermore, we have used the antioxidant PDTC as a molecular probe to identify two additional regulatory pathways that differentially regulate the expression of the adhesion molecule genes ICAM- 1 and E-selectin in response to the same activating signal. Both ICAM-1 and E-selectin gene expression were insensitive to inhibition compared to VCAM-1 at the concentrations of PDTC used $(50 \mu \mathrm{M})$. This is further supported by dose-response studies in which IL- $1 \beta$ activation of VCAM-1 expression was inhibited by 5-50 $\mu \mathrm{M}$ PDTC while peak E-selectin expression at $4 \mathrm{~h}$ was unaffected up to $100 \mu \mathrm{M}$ (data not shown). Nevertheless, these studies cannot rule out the possibility of a PDTC inhibitable component of E-selectin and ICAM-1 gene expression at significantly higher concentrations (i.e., millimolar range). Characterization of this VCAM1-specific molecular regulatory pathway from the functional expression of cell adhesion to a specific DNA binding protein complex suggests that redox mechanisms may play an important role in differentially regulating the expression of these three adhesion molecule genes in response to otherwise nondiscriminatory activating signals.

In the case of receptor mediated signals, such as IL- $1 \beta$ and $\mathrm{TNF} \alpha$, the initial intracellular signals activated by the interaction of ligand with receptor were unlikely to be affected by PDTC. This implies that while VCAM-1, ICAM-1, and E-selectin share common regulatory signals immediately after receptor activation, the final regulatory signals are mediated by gene-specific signal transduction mechanisms. Similarly, initial signals activated by LPS and PIC, while less well character- 
ized, would also appear to be shared among all three adhesion molecule genes while final regulatory signals are gene specific. These studies also suggest, but do not prove, that TNF $\alpha$, IL- $1 \beta$, LPS and PIC all activate VCAM-1 expression through a common, PDTC-sensitive regulatory factor.

Regulation of VCAM-1 mRNA accumulation appears to be the primary target for PDTC mediated inhibition of VCAM1 gene expression. In response to $\mathrm{TNF} \alpha$, PDTC blocked VCAM-1-mediated cell adhesion, protein accumulation, and mRNA accumulation each to a similar degree. This suggests that the mechanism of PDTC action primarily involves transcriptional or posttranscriptional regulation of VCAM-1 mRNA accumulation rather than translational or posttranslational regulation of VCAM-1 protein expression. A role for transcriptional mechanisms mediating PDTC action was suggested further by DNA transfection experiments demonstrating the ability of PDTC to block activation of the human VCAM-1 promoter by TNF $\alpha$ and LPS. Nevertheless, it is still unknown to what degree posttranscriptional mechanisms involving RNA processing or mRNA stability may play in VCAM-1 gene expression as have been demonstrated for E-selectin (37) and ICAM-1 (38).

Although an effect on a redox mechanism is inferred, this study does not identify the specific redox biochemistry mediating PDTC's regulatory effect. However, our studies indirectly suggest that PDTC functions through mechanisms related to its thiol antioxidant properties. In support of this, the structurally unrelated, thiol antioxidant NAC also effectively inhibited the activation of VCAM-1. Similar results were obtained with another dithiocarbamate, diethyldithiocarbamate (data not shown). Whether these are due to redox reactions involving direct modification by an oxygen radical or through glutathione-dependent oxidation reactions is not yet known. In support of glutathione-dependent redox reactions, both dithiocarbamates and NAC are effective thiol delivery agents that increase intracellular levels of glutathione (39). In addition, we have observed that an agent that depletes glutathione level in the cell, L-buthionine-sulfoximine, augmented VCAM-1 expression in response to cytokine activation (Marui and Medford, manuscript in preparation ). In support of direct modification by an oxygen radical, TNF $\alpha$ and IL- 1 induce the synthesis of oxygen radicals in both lymphoid and nonlymphoid cells $(19,20)$. NAC and dithiocarbamates may also react directly with oxygen radicals induced by various activators in HUVE cells while dithiocarbamates may inhibit oxygen radical formation through chelation of intracellular metal ions and blockade of the Haber-Weiss-Fenton reaction (40). An assignment of the relative role of each redox mechanism will require careful manipulation and measurements of specific reactive oxygen species, glutathione levels and other redox regulatory mechanisms in HUVE cells.

Central to an understanding of the mechanism by which an oxidative signal regulates VCAM-1 gene expression, we have identified candidate, antioxidant-sensitive transcriptional regulatory proteins. Recent studies of the human VCAM-1 promoter have demonstrated that TNF $\alpha$ activation of VCAM-1 transcriptional in endothelial cells is dependent on two closely linked NF- $\kappa$ B-like DNA binding elements located at promoter coordinates -77 and $-63(22,23)$. Our DNA transfection and gel mobility shift studies strongly suggest that LPS utilizes a similar, NF- $\kappa$ B-like mechanism of transcriptional activation as TNF $\alpha$. In both cases, this transactivation mechanism, as well as NF- $\kappa$ B-like DNA binding activity, was blocked by the an- tioxidant PDTC. These results suggest that PDTC inhibits activation of VCAM-1 gene transcription and expression in HUVE cells through inhibition of NF- $\kappa$ B-like transcriptional regulatory proteins.

$N F-\kappa B$ is a ubiquitously expressed multisubunit transcription factor that is activated by diverse signals (see reference 41 for review) possibly through phosphorylation of the $I_{k} B$ subunit and its dissociation from the inactive cytoplasmic complex followed by translocation of the active dimer of p50 and p65 to the nucleus (42). Antioxidants such as NAC and other cysteine derivatives inhibit NF- $\kappa \mathrm{B}$-driven transcription of the HIV-1 $(25,43,44)$ and HIV-1 viral replication (43). In several immortalized cell lines, NF- $\kappa$ B is activated by diverse stimuli such as TNF $\alpha$, IL- $1 \beta$, LPS, and PIC, and inhibited by the antioxidants PDTC and NAC $(24,25)$. Our studies demonstrate a similar pattern of antioxidant-sensitive activation of both VCAM- 1 expression and NF- $\kappa$ B-like activity in HUVE cells. However, it is not known whether the NF- $\kappa \mathrm{B}$ binding activity that we and others observe in primary HUVE cells $(22,37,45)$ represents the same, or different, protein complexes activated in immortalized cell lines. Nevertheless, our studies support the notion that oxidative signals play a significant role in regulating VCAM-1 gene expression in HUVE cells through modulation of NF- $\mathrm{B}$-like transcriptional regulatory factors.

While our studies support the notion that NF- $\mathrm{B}$-like factors are necessary to activate VCAM-1 gene expression in endothelial cells $(22,23)$, they raise important questions as to the role of NF- $\kappa$ B in E-selectin and ICAM-1 gene expression. Based on DNA transfection analysis of deleted promoter constructs of E-selectin gene, a cis-acting promoter element containing a NF- $\kappa \mathrm{B}$ consensus binding site was found to be necessary to mediate transcriptional activation by $\operatorname{IL}-1 \beta(37,45)$. Yet, we found that PDTC did not inhibit the induction of E-selectin mRNA levels. The inhibition of NF- $\kappa$ B-like activation but not E-selectin gene expression by PDTC argues against NF- $\kappa \mathrm{B}-$ like transcriptional factors as essential components in E-selectin gene activation. Similarly, these same inducible factors do not appear to be essential in the activation of ICAM-1 expression despite the presence of NF- $\kappa$ B consensus DNA binding sites on the ICAM-1 promoter $(46,47)$.

These apparently conflicting conclusions on the role of NF$\kappa \mathrm{B}$ in endothelial cell gene expression illustrate both differences in experimental approach as well as the complexity of the NF$\kappa B$ transcriptional complex. The notion of a "consensus" NF$\kappa B$ DNA binding site has been called into question as different "consensus" sites appear to elicit very different binding and transcriptional activation properties of $\mathrm{NF}-\kappa \mathrm{B}(48)$. Similarly, differential competition for NF- $\kappa$ B binding sites by the $p 50 /$ p65 heterodimer (NF- $\mathrm{B}$ ) or p50 and p65 homodimers may be determined by slight differences in the DNA "consensus" sequence (49). The interaction of NF- $\kappa$ B with other transcriptional factors might also influence binding and transactivation of VCAM- 1 and thus the association of the NF- $\kappa$ B site with other DNA binding sites is likely crucial $(22,23)$. In the case of E-selectin, other additional transcriptional and posttranscriptional mechanisms regulate E-selectin gene expression (37). The relative contributions of NF- $\kappa$ B and these other factors in regulating E-selectin gene expression are not known. Furthermore, in contrast to E-selectin, which has only one NF- $\kappa$ B site, VCAM-1 has two closely linked NF- $\kappa$ B binding sites. The 5' $\mathrm{NF}-\kappa \mathrm{B}$ binding site shows incomplete consensus sequence by one base (50), yet both sites are necessary for activation of VCAM-1 gene $(22,23)$. As each of these sites may bind differ- 
ent protein complexes, the interaction between both NF- $\kappa \mathrm{B}$ binding sites may contribute to the transactivation of the VCAM-1 gene $(22,23)$.

Tissue-specific, transformation-specific and possibly cytokine-specific factors may both play roles in modulating adhesion molecule gene expression. Indeed, we did observe a modest decrease in the peak E-selectin mRNA accumulation in PDTC-treated HUVE cells exposed to TNF $\alpha$ but not to IL- $1 \beta$, LPS or PIC after $4 \mathrm{~h}$. This raises the possibility that TNF $\alpha$ and IL- $1 \beta$ may activate E-selectin gene expression through distinct molecular mechanisms distinguishable by their sensitivity to inhibition by PDTC. In human dermal microvascular endothelial cells, TNF $\alpha$ but not IL-1 induces VCAM-1 while both TNF $\alpha$ and IL-1 each induce ICAM-1 expression (15). These studies support the notion that TNF $\alpha$ and IL-1 may function through distinct molecular mechanisms in endothelial cells. Tissue-specific and/or transformation-specific transcriptional regulatory factors may also play a role in regulating ICAM-1 gene expression. Deletion analysis of the $5^{\prime}$ flanking region of the ICAM-1 promoter demonstrates that an NF- $\kappa$ B binding site serves as a transcriptional activator in adenocarcinoma and fibrosarcoma cell lines (46) but is apparently not necessary for cytokine activation in primary human vascular endothelial cells (W. Caughman, personal communication).

Our study does not address the important issue of whether the ICAM-1 or E-selectin NF- $\kappa$ B-like elements regulate cytokine activation of either promoter through a PDTC-sensitive or -insensitive process in primary HUVE cells. Thus, the precise molecular mechanism (s) by which E-selectin and ICAM1 gene expression "escapes" inhibition by PDTC remains an important unresolved question. To determine whether PDTC sensitive transcriptional regulation is restricted to VCAM-1 or is a feature of other vascular endothelial genes will require a comprehensive survey of transcriptional responses. To this end, we have identified the cytokine IL- 6 gene as exhibiting a similar pattern of PDTC-sensitive cytokine activation as VCAM- 1 in human vascular endothelial cells (M. Offermann, personal communication). Interestingly, NF- $\kappa$ B activation also plays an important role in the regulation of IL- 6 gene expression $(51,52)$. This suggests that PDTC-sensitive regulation of gene expression may define a distinct network of genes involved in inflammation and in the atherosclerotic setting.

Atherosclerosis is a chronic disease of the arterial intima characterized by the focal accumulation of leukocytes, smooth muscle cells, lipids, and extracellular matrix. Current hypotheses concerning its pathogenesis focus on the modification of LDL into oxidatively-modified LDL (ox-LDL) (53). For example, inhibition of LDL oxidation with the antioxidant probucol (53) inhibits the progression of atherosclerotic lesions in LDL receptor-deficient rabbits $(54,55)$. Our studies suggest the mechanism by which antioxidants inhibit atherosclerosis may not be solely due to their ability to inhibit oxidation of LDL. Probucol and other antioxidants may also function by blocking specific, intracellular, redox-sensitive signal transduction pathways involved in atherogenesis. Thus, a therapeutically important feature of antioxidants in atherosclerosis may be due to direct alterations in the metabolism and function of endothelial, smooth muscle, and inflammatory cells. Our studies establish a potential molecular linkage between the redox state of the vascular endothelial cell and VCAM-1 gene expression that expands on the notion of oxidation as an important intracellular regulatory signal that mediates the selective expression of VCAM-1 and consequent mononuclear leukocyte accumulation observed early in the pathogenesis of atherosclerosis.

Our studies suggest that an increase in the endothelial cell oxidative state may sensitize the vasculature to otherwise physiologic signals resulting in abnormally elevated expression of adhesion molecules such as VCAM-1 and other gene products involved in the inflammatory response. Conversely, the maintenance of a low endothelial oxidative state may desensitize the vasculature to normal or even elevated levels of these same signals. In this context, the specific target of either natural or synthetic antioxidants would be specific regulatory factor(s) that transduces metabolic signals (i.e., oxidation) into nuclear regulatory signals (i.e., expression of adhesion molecule genes). In addition to atherosclerosis, this model may have significant therapeutic implications in a variety of other disease states involving VCAM-1 expression.

\section{Acknowledgments}

We would like to thank Drs. Hanh T. Nguyen and Wright Caughman for helpful discussions and critical reading of the manuscript and the expert technical assistance of Mr. Eddie Cruet and Ms. Lyn Olliff and secretarial support of Ms. Jenny Dennis.

This work was supported in part by National Institutes of Health , grant PO1 HL48667 (Drs. Alexander and Medford subproject). Dr. Medford is an Established Investigator of the American Heart Association.

\section{References}

1. Butcher, E. 1992. Leukocyte-endothelial cell recognition: three (or more) steps to specificity and diversity. Cell. 67:1033-1036.

2. Pober, J. S., and R. S. Cotran. 1991. What can be learned from the expression of endothelial adhesion molecules in tissues? Lab. Invest. 64:301-305.

3. Cybulsky, M. I., and M. A. J. Gimbrone. 1991. Endothelial expression of a mononuclear leukocyte adhesion molecule during atherogenesis. Science (Wash. DC). 251:788-791.

4. Elices, M. J., L. Osborn, Y. Takada, C. Crouse, S. Luhowskyj, M. E. Hemler, and R. R. Lobb. 1990. VCAM-1 on activated endothelium interacts with the leukocyte integrin VLA-4 at a site distinct from the VLA-4/fibronectin binding site. Cell. 60:577-584.

5. Bochner, B. S., F. W. Luscinskas, M. A. J. Gimbrone, W. Newman, S. A. Sterbinsky, A. C. P. Derse, D. Klunk, and R. P. Schleimer. 1991. Adhesion of human basophils, eosinophils, and neutrophils to interleukin 1-activated human vascular endothelial cells: contributions of endothelial cell adhesion molecules. $J$. Exp. Med. 173:1553-1557.

6. Carlos, T., N. Kovach, B. Schwartz, M. Rosa, B. Newman, E. Wayner, C. Benjamin, L. Osborn, R. Lobb, and J. Harlan. 1991. Human monocytes bind to two cytokine-induced adhesive ligands on cultured human endothelial cells: endothelial-leukocyte adhesion molecule-1 and vascular cell adhesion molecule-1. Blood. 77:2266-2271.

7. Oppenheimer, M. N., L. S. Davis, D. T. Bogue, J. Ramberg, and P. E. Lipsky. 1991. Differential utilization of ICAM-1 and VCAM-1 during the adhesion and transendothelial migration of human $\mathrm{T}$ lymphocytes. J. Immunol. 147:2913-2921.

8. van Dinther Janssen, A. C., E. Horst, G. Koopman, W. Newmann, R. J. Scheper, C. J. Meijer, and S. T. Pals. 1991. The VLA-4/VCAM-1 pathway is involved in lymphocyte adhesion to endothelium in rheumatoid synovium. $J$. Immunol. 147:4207-4210.

9. Burkly, L. C., A. Jakubowski, B. M. Newman, M. D. Rosa, R. G. Chi, and R. R. Lobb. 1991. Signaling by vascular cell adhesion molecule-1 (VCAM-1) through VLA-4 promotes CD3-dependent T cell proliferation. Eur. J. Immunol. 21:2871-2875.

10. Poston, R. N., D. O. Haskard, J. R. Coucher, N. P. Gall, and T. R. R. Johnson. 1992. Expression of intercellular adhesion molecule- 1 in atherosclerotic plaques. Am. J. Pathol. 140:665-673.

11. Cybulsky, M., M. Allan-Motamed, B. Medoff, V. Davis, T. Collins, and M. Gimbrone. 1992. Endothelial expression of leukocyte adhesion molecules during atherogenesis in the rabbit. FASEB J. 6:A1030. (Abstr.)

12. Montgomery, K. F., L. Osborn, C. Hession, R. Tizard, D. Goff, C. Vassallo, P. I. Tarr, K. Bomsztyk, R. Lobb, J. M. Harlan, and T. H. Pohlman. 1991. Activation of endothelial-leukocyte adhesion molecule 1 (ELAM-1) gene transcription. Proc. Natl. Acad. Sci. USA. 88:6523-6527. 
13. Offermann, M., M. Hagan, and R. Medford. 1992. Regulation of endothelial cell surface adhesion molecule gene expression by synthetic and viral double stranded RNA. J. Cell. Biochem. 16A:52. (Abstr.)

14. Kyan, A. U., D. O. Haskard, R. N. Poston, M. H. Thornhill, and T. H. Lee. 1991. Endothelial leukocyte adhesion molecule- 1 and intercellular adhesion molecule-1 mediate the adhesion of eosinophils to endothelial cells in vitro and are expressed by endothelium in allergic cutaneous inflammation in vivo. $J$. Immunol. 146:521-528.

15. Swerlick, R. A., K. H. Lee, L. J. Li, N. T. Sepp, S. W. Caughman, and T. J. Lawley. 1992. Regulation of vascular cell adhesion molecule 1 on human dermal microvascular endothelial cells. J. Immunol. 149:698-705.

16. Thornhill, M. H., and D. O. Haskard. 1990. IL-4 regulates endothelial cell activation by IL-1, tumor necrosis factor, or IFN- $\gamma$. J. Immunol. 145:865-872.

17. Sparrow, C. P., and J. Olszewski. 1992. Cellular oxidative modification of low density lipoprotein does not require lipoxygenases. Proc. Natl. Acad. Sci. USA. 89:128-131.

18. Morel, D. W., P. E. DiCorleto, and G. M. Chisolm. 1984. Endothelial and smooth muscle cells alter low density lipoprotein in vitro by free radical oxidation. Arteriosclerosis. 4:357-364.

19. Meier, B., H. H. Radeke, S. Selle, M. Younes, H. Sies, K. Resch, and G. G. Habermehl. 1989. Human fibroblasts release reactive oxygen species in response to interleukin-1 or tumor necrosis factor- $\alpha$. Biochem. J. 263:539-545.

20. Warner, B. B., M. S. Burhans, J. C. Clark, and J. R. Wispe. 1991. Tumor necrosis factor- $\alpha$ increases $\mathrm{Mn}$-SOD expression: protection against oxidant injury. Am. J. Physiol. 260:L296-L301.

21. Li, H., M. Cybulsky, M. Gimbrone, and P. Libby. 1993. An atherogenic diet rapidly induces VCAM-1, a cytokine-regulatable mononuclear leukocyte adhesion molecule, in rabbit aortic endothelium. Arterioscler. Thromb. 13:197204.

22. Iademarco, M. F., J. J. McQuillan, G. D. Rosen, and D. C. Dean. 1992. Characterization of the promoter for vascular cell adhesion molecule-1 (VCAM1). J. Biol. Chem. 267:16323-16329.

23. Neish, A., A. Williams, H. Palmer, M. Whitley, and T. Collins. 1992. Functional analysis of the human vascular cell adhesion molecule 1 promoter. $J$. Exp. Med. 176:1583-1593.

24. Schreck, R., P. Rieber, and P. A. Baeuerle. 1991. Reactive oxygen intermediates as apparently widely used messengers in the activation of the NF- $\kappa$ B transcription factor and HIV-1. EMBO (Eur. Mol. Biol. Organ. J. 10:2247-2258.

25. Schreck, R., B. Meier, D. N. Mannel, W. Droge, and P. A. Baeurle. 1992. Dithiocarbamates as potent inhibitors of nuclear factor $\mathrm{\kappa B}$ activation in intact cells. J. Exp. Med. 175:1181-1194.

26. Schreck, R., and P. Baeuerle. 1991. A role for oxygen radicals as second messengers. Trends Cell Biol. 1:39-42.

27. Chomczynski, P., and N. Sacchi. 1987. Single-step method of RNA isolation by acid guanidinium thiocyanate-phenol-chloroform extraction. Anal. Biochem. 162:156-159.

28. Feinberg, A. P., and B. Vogelstein. 1983. A technique for radiolabeling DNA restriction endonuclease fragments to high specific activity. Anal. Bioch. 132:6-13.

29. Osborn, L., C. Hession, R. Tizard, C. Vassallo, S. Luhowskyj, R. G. Chi, and R. Lobb. 1989. Direct expression cloning of vascular cell adhesion molecule 1, a cytokine-induced endothelial protein that binds to lymphocytes. Cell. 59:1203-1211.

30. Staunton, D. E., S. D. Marlin, C. Stratowa, M. L. Dustin, and T. Springer. 1988. Primary structure of ICAM-1 demonstrates interaction between members of immunoglobulin and integrin supergene families. Cell. 52:925-933.

31. Bevilacqua, M. P., S. Stengelin, M. A. J. Gimbrone, and B. Seed. 1989. Endothelial leukocyte adhesion molecule 1: an inducible receptor for neutrophils related to complement regulatory proteins and lectins. Science (Wash. DC.). 243:1160-1165.

32. Ausubel, F., R. Brent, R. Kingston, D. Moore, J. Seidman, J. Smith, and K. Struhl. 1989. Current Protocols in Molecular Biology. John Wiley \& Sons, Inc., New York.

33. Bradford, M. 1976. A rapid and sensitive method for the quantitation of microgram quantities of protein utilizing the principle of protein-dye binding. Anal. Biochem. 72:248-254.

34. Dignam, J., R. Lebovitz, and R. Roeder. 1983. Accurate transcription initiation by RNA polymerase II in a soluble extract from isolated mammalian nuclei. Nucleic Acids Res. 11:1476-1489.
35. Lo, S. K., G. A. Van Seventer, S. M. Levin, and S. D. Wright. 1989. Two leukocyte receptors (CD1 la/CD18 and CD11b/CD18) mediate transient adhesion to endothelium by binding to different ligands. J. Immunol. 143:3325-3329.

36. Carlos, T. M., B. R. Schwartz, N. L. Kovach, E. Yee, M. Rosso, L. Osborn, R. G. Chi, B. Newman, R. Lobb, and J. M. Harlan. 1990. Vascular cell adhesion molecule-1 mediates lymphocyte adherence to cytokine-activated cultured human endothelial cells [published erratum appears in Blood Dec. 1 1990; 76(11):2420]. Blood. 76:965-970.

37. Ghersa, P., R. H. van Huijsduijnen, J. Whelan, and J. F. DeLamarter. 1992. Labile proteins play a dual role in the control of endothelial leukocyte adhesion molecule-1 (ELAM-1) gene regulation. J. Biol. Chem. 267:1922619232.

38. Wertheimer, S. J., C. L. Myers, R. W. Wallace, and T. P. Parks. 1992. Intercellular adhesion molecule-1 gene expression in human endothelial cells differential regulation by tumor necrosis factor- $\alpha$ and phorbol myristate acetate. J. Biol. Chem. 267:12030-12035.

39. Perchellet, E. M., E. A. Maatta, N. L. Abney, and J.-P. Perchellet. 1987 Effects of diverse intracellular thiol delivery agents on glutathione peroxidase activity, the ratio of reduced/oxidized glutathione, and ornithine decarboxylase induction in isolated mouse epidermal cells treated with 12-o-tetradecanoylphorbol-13-acetate. J. Cell Physiol. 131:64-73.

40. Saran, M., and W. Bors. 1990. Radical reactions in vivo-an overview. Radiat. Environ. Biophys. 29:249-262.

41. Lenardo, M. J., and D. Baltimore. 1989. NF- $\kappa$ B: a pleiotropic mediator of inducible and tissue-specific gene control. Cell. 58:227-229.

42. Ghosh, S., and D. Baltimore. 1990. Activation in vitro of NF- $\kappa$ B by phosphorylation of its inhibitor I $\kappa$ B. Nature (Lond.) 344:678-682.

43. Mihm, S., J. Ennen, U. Pessara, R. Kurth, and W. Droge. 1991. Inhibition of HIV-1 replication and NF- $\mathrm{B}$ activity by cysteine and cysteine derivatives. AIDS. 5:497-503.

44. Staal, F. J., M. Roederer, L. A. Herzenberg, and L. A. Herzenberg. 1990. Intracellular thiols regulate activation of nuclear factor $\kappa \mathbf{B}$ and transcription of human immunodeficiency virus. Proc. Natl. Acad. Sci. USA. 87:9943-9947.

45. Whelan, J., P. Ghersa, R. H. van Huijsduijnen, J. Gray, G. Chandra, F Talabot, and J. F. DeLamarter. 1991. An NF $\kappa$ B-like factor is essential but not sufficient for cytokine induction of endothelial leukocyte adhesion molecule 1 (ELAM-1) gene transcription. Nucleic Acids Res. 19:2645-2653.

46. Voraberger, G., R. Schafer, and C. Stratowa. 1991. Cloning of the human gene for intercellular adhesion molecule 1 and analysis of its 5 '-regulatory region. Induction by cytokines and phorbol ester. J. Immunol. 147:2777-2786.

47. Degitz, K., L. J. Li, and S. W. Caughman. 1991. Cloning and characterization of the 5'-transcriptional regulatory region of the human intercellular adhesion molecule 1 gene. J. Biol. Chem. 266:14024-14030.

48. Fujita, T., G. Nolan, S. Ghosh, and D. Baltimore. 1992. Independent modes of transcriptional activation by the p50 and $\mathrm{p} 65$ subunits of NF- $\kappa \mathrm{B}$. Genes Dev. 6:775-787.

49. Kunsch, C., S. M. Ruben, and C. A. Rosen. 1992. Selection of optimal $\kappa \mathrm{B} /$ Rel DNA binding motifs: interaction of both subunits of NF- $\kappa$ B with DNA is required for transcriptional activation. $\mathrm{Mol}$. Cell. Biol. 12:4412-4421.

50. Baeuerle, P. A. 1991. The inducible transcription activator NF- $\kappa$ B: regulation by distinct protein subunits. Biochim. Biophys. Acta. 1072:63-80.

51. Shimizu, H., K. Mitomo, T. Watanabe, S. Okamoto, and K. Yamamoto. 1990. Involvement of a NF- $\kappa$ B-like transcription factor in the activation of the interleukin-6 gene by inflammatory lymphokines. Mol. Cell. Biol. 10:561-568.

52. Libermann, T. A., and D. Baltimore. 1990. Activation of interleukin-6 gene expression through the NF- $\mathrm{k}$ B transcription factor. Mol. Cell. Biol. 10:2327-2334.

53. Parthasarathy, S., S. G. Young, J. L. Witztum, R. C. Pittman, and D. Steinberg. 1986. Probucol inhibits oxidative modification of low density lipoprotein. J. Clin. Invest. 77:641-644.

54. Carew, T. E., D. C. Schwenke, and D. Steinberg. 1987. Antiatherogenic effect of probucol unrelated to its hypocholesterolemic effect: evidence that antioxidants in vivo can selectively inhibit low density lipoprotein degradation in macrophage-rich fatty streaks and slow the progression of atherosclerosis in the Watanabe heritable hyperlipidemic rabbit. Proc. Natl. Acad. Sci. USA. 84:77257729.

55. Kita, T., Y. Nagano, M. Yokode, K. Ishii, N. Kume, S. Narumiya, and C. Kawai. 1988. Prevention of atherosclerotic progression in Watanabe rabbits by probucol. Am. J. Cardiol. 62:13B-19B. 